\title{
Canada's Role in International Organizations, Trade Negotiations and Sanctions
}

\author{
Kreshnik Aliaj ${ }^{1} \&$ Genc Mekaj $^{1}$ \\ ${ }^{1}$ Iliria College, Kosovo \\ Correspondence: Kreshnik Aliaj, Iliria College, Kosovo. E-mail: kreshnik.k.a1980@gmail.com
}

Received: September 1, 2018

Accepted: September 21, $2018 \quad$ Online Published: September 28, 2018

doi:10.5539/ijef.v10n10p131

URL: https://doi.org/10.5539/ijef.v10n10p131

\begin{abstract}
In this era where international regional integration and processes to promote globalization are at the forefront of political issues on the world stage, every region of the world, whether sovereign or non-sovereign, is seeking in this globalization mechanism to promote its interests, be they cultural, political or economic. At various levels, Canada, like other territories around the world, is trying to play its game well in this international context, as well as placing its pawns on the world stage. Canada is distinguished for a difficult relationship with the multilateral world, renounced by a number of international councils. The Government of Canada should be more cautious about complicated multilateral processes and should have a good review of all the organizations it is part of.
\end{abstract}

Keywords: International organizations, trade agreements, obligations, sanctions

\section{Introduction}

Canada has often been characterized as a state against multilateralism what has caused its status to be lower in recent years. The Canadian government favor foreign governmental groups as G-8 or G-20 where supremacy is free and consensus of key players is the rule (Kahler, 1992).

Canada is still uncertain about how to treat international organizations on the international scene as independent actors. It seems that the Canadian government is less vulnerable to geopolitical issues such as climate change. Therefore, Canada's departure from the United Nations Convention against Drought has been interpreted by some as "a departure from global citizenship".

There is an opinion that Canada's conservative government has given up some of the main principles that gave it reliability on the international scene as a dedication to human security, a preference for multilateral diplomacy, and a desire to improve the normative frame within which international organizations make great efforts (De Kerckhove, 2008).

When continuing to engage in funding for functional international organizations, the Canadian government has not too much interest in devoting time and efforts to improve the productiveness of the UN and its accompanying tool of global governance. It seems like the Canadian government blames organizations for lack of responsibility or value-based management.

\section{What Are International Organizations?}

"The requirement for international security involves the unconditional surrender of all states to a certain extent of its freedom of action and its sovereignty, and it should be clear beyond any doubt that no other way can lead to one such security." (Albert Einstain)

International organizations are a form of institution that refers to a formal system with rules and objectives with a rational administrative instrument that carries a technical form and material organization such as constitutions, local chapters, machinery, work tools, emblems, logos, staff, an administrative hierarchy etc. International organizations are also a permanent community of a governmental or non-governmental nature created on the basis of an international agreement for the purpose of cooperation in resolving the international problems envisaged in those documents. From this definition emerges that international organizations are created with the will of states, thus the founders of international organizations are sovereign states when organizations are stateowned and they are created based on an international treaty. Their activity is also extended within the 
competencies stipulated in the agreement.

International organizations are classified into two main categories: intergovernmental organizations (IGO) and non-governmental organizations (INGOs). An intergovernmental organization (IGO) is an organization composed mainly of sovereign states often referred to as member states or other intergovernmental organizations. Intergovernmental organizations are often called international organizations, although this term may include non-governmental international organizations such as international non-profit organizations (NGOs) or multinational corporations (Note 1).

In another aspect, organizations are classified based on geographic extent and membership. In this classification we have two types of global and regional organizations. The regional organization sees itself in places of a similar kind to solve problems that could not be tackled at the national level and which would be treated inefficiently from the broader institutions. The regional organization has a limited number of members, many of whom are geographically, economically and politically similar. This would certainly bring security against external threats. Meanwhile, global organizations have their own countries from around the world. They form the basis for collective security for the issue of peace and prosperity (Malltezi, 2009).

The goals and objectives of international organizations are often multiple and in the public interest, but they can be created for a specific purpose. International organizations prescribe and define their goals in statutes or other founding documents. But it happens and that organizations have other purposes other than those defined in the status. What differentiates the two main types of organizations is that intergovernmental organizations are international organizations, members of which are states. While non-governmental organizations are associations that consist of members such as individuals and groups. They are transnational organizations made up of private citizens holding a consultative status. They include professional associations, foundations, multinational corporations or active international groups in different countries that join together to work on common interests (Kangley).

In the world policy trend there is a rise in the number of non-governmental organizations. NGOs are many such as AI, the International Federation of Red Cross and Crescent, Oxfam International, CARE, Save the Children etc. NGOs perform a number of functions. They furnish details and practical proficiency to governments and international organizations on various international areas.

Many other organizations serve as a platform for negotiating and creating coalitions and making decisions. In this regard, international organizations provide points of contact to discuss, collaborate, argue, etc (Malltezi, 2009). International organizations are often recognized as international regimes. This is because together with the states intergovernmental organizations lead the creation of international rules and principles. The cards of these organizations include the norms, rules and decision-making processes of the regimes (Thompson \& Snidal, 1999). Thus, the principles of the international regime are defined in a number of international treaties. Organizations institutionalize these principles and rules that will then dictate how states will act in accordance with these norms and principles.

\section{International Organization Membership of Canada}

Canada promotes common values such as equality and democracy through its participation in many international organizations:

Canada is part of African Development Bank and Asian Development Bank as an nonregional member. It is parto of Agence de Coopération Culturelle et Technique, Arctic Council, Caribbean Development Bank, Commonwealth of Nations, Community of Democracies. Canada is part of Council of Europe as an observer, Asean Regional Forum, Democratic 10-D10, ASEAN, Association of Southeast Asian Nations, Asia Pacific Economic Cooperation, Diplomatic Forum, Euro-Atlantic Partnership Council, European Bank for Reconstruction and Development, European Space Agency.

Canada's participates in Food and Agriculture Organization, OIF, G20, G-7, G8, G-10, IFC, Inter-American Development Bank, International Atomic Energy Agency, International Bank for Reconstruction and Development, International Civil Aviation Organization, International Criminal Court, International Development Association, International Energy Agency, International Federation of Red Cross and Red Crescent Societies, International Fund for Agricultural Development, International Hydrographic Organization, International Indigenous Affairs.

Moreover, it is part of a number of organizations such as UNESCO, North Atlantic Treaty Organization, United Nations, World Health Organization, World Trade Organization, Humanitarian assistance, International Labour Organization, La Francophonie, Organization for Economic Cooperation and Development, Organization for 


\section{Security and Co-operation in Europe etc.}

\section{Canada's Relationship with International Organizations}

\subsection{Canada and the UN}

The UN is the organization on whose agenda means all areas of human activity, everywhere in the world. Through this organization, the different opinions shared by the member states are expressed. There are 191 member states that make possible the operation of this organization. Since the UN establishment, Canada has been a lot involved in the organization. Canada is remarkable for its important role within the United Nations, making Canada one of the key countries for many UN achievements.

The goals and objectives of the UN are:

- $\quad$ Securing and preserving nation-wide peace;

- Preservation, security and development of relations between member states;

- Providing assistance in solving economic, social affairs and efforts for a future and a better life for all people.

These and many other purposes are the basis of the United Nations. For nearly half a century, Canada has made a very important contribution in all areas of UN activity: providing peace, security, development assistance, influencing human rights observance, and influencing development economic, social and environmental issues.

As a basis for building a system created under some rules, the United Nations Organization serves to influence major issues in the world to protect global security, promotes economic interests and gives value to the interference that Canada has in dealing with respect for individual. The UN, along with Canada help, has been promoting the evolution of international affairs.

Including a range of human rights and justice, reducing environmental destruction, reducing poverty and promoting human development and human security at global level is achieved only through multinational discussions and negotiations. The only force that achieves this is the UN. For this reason, the UN is heavily involved in the entire Canadian society. Both need each other. The White Paper on Foreign Policy of 1995, Canada and the World, clearly stated that:

\subsection{Canada and the EU}

Canada has a close relationship with the European Union in various respects. A number of issues have been included in their cooperation, both national and international. Canada has co-operated with the EU to resolve several crises around the world. The EU is the second partner, the second most important source of foreign investment and the starting point for a number of investments Canada has made abroad. The EU is also an important collaborator for scientific and technological relations as well as a key point for new technologies in Canada.

\subsection{Canada and the Council of Europe}

Canada oversees and monitors the Ministerial Committee and the Parliamentary Assembly of the Council of Europe. The Canadian government is part of the annual sessions of the Assembly with a certain delegation, while other Canadian officials are part of the meetings of the Council of Ministers, Reporting Groups and others.

\subsection{Canada and NATO}

The North Atlantic Treaty, which was signed in April 1949, has been the starting point for the establishment of the North Atlantic Treaty Organization. This political and military alliance was established with a view to protecting its peoples, based on democracy. NATO has three main tasks, security, crisis management and defense.

Canada was a founding member of the Alliance and has remained as a member since its inception. NATO contributes to global security and peace and has an important role in Canadian security and defence policy.

Canada's priority for NATO is to ensure the Alliance remains modern, flexible, agile and able to face current and future threats. This makes Canada work its efforts to establish a parity between NATO and non-member countries.

This alliance was Canada's main multilateral forum for its transatlantic relations. NATO remains one of the leading organizations where Canada is committed to security security, where its contributions have been scarce and here we mention NATO's mission in Afghanistan. 


\subsection{Canada and the OSCE}

This organization works to alleviate conflicts, manage crises and regulate post-conflict relations in the European and Eurasian regions. The Canadian government collaborates with many OSCE bodies on human related security issues, such are the post-conflict rehabilitation of civilians, addressing the root causes of terrorism, and promoting arms control issues. Canada provides funding for a number of projects under the OSCE. Canadian parliamentarians have been very active in the OSCE Parliamentary Assembly, including as committee chairs and as reporters.

\section{Canada's priorities at the OSCE}

The OSCE's task fits in with Canadian foreign policy in support of human rights and fundamental freedoms; to help the countries in need; as well as supporting democracy, the law; and prevents conflict, promotes good governance. Canada strongly supports the OSCE and the operations it undertakes. Parts of the Canadian parliament engage in the work of the OSCE Parliamentary Assembly.

\subsection{Canada and the Arctic Council}

The Arctic Council was established by the Ottawa Declaration in 1996. Canada was its first Chair and has participated actively in the work of the Council. The Canadian government has also developed its circumpolar policy through closer cooperation with the European Union (e.g., the 1999 Joint Statement on Northern Cooperation) and the Northern Dimension of Canada's Foreign Policy (2000). Canada is a participant of the Arctic Region conference that is organized every two years and sends representatives to the Standing Committee of Parliamentarians of the Arctic Region.

Canada participates actively in the work of the Arctic Council which has six main tasks:

- $\quad$ ACAP which focuses on environmental issues;

- AMAP which monitores, assesses and prevents pollution in the Arctic (Environment and Climate Change Canada);

- $\quad$ CAFF whose main focus is biodiversity conservation and sustainability;

- $\quad$ EPPR whose main concern is to prevent the environmental emergencies;

- PAME which is focused to prevent the pollution that deals with Arctic marine environment issues.

- The last one is SDWG whose focus are the living conditions of Arctic residents (Indigenous and Northern Affairs Canada).

\subsection{Canada and the World Trade Organization}

The WTO helps create trade rules among its 164 members. Canada as a state supports the multinational trade system with the WTO. Canada enables the provision of workers' employment by participating in the WTO, which provides a framework for pursuing objectives on a global scale.

The WTO is responsible for the administration of WTO trade agreements, it is responsible also for the provision of a forum for trade negotiations, it holds trade disputes. WTO is responsible for monitoring the members' trade policies to help ensure compliance the WTO's trade agreements and finally it administers technical assistance and training for developing countries.

\section{Canada International Trade Agreements}

Canada's participation in various trade agreements comes as a result of the many natural resources it owns, but it must provide more access to international markets.

According to the Constitution and Canadian case law, the federal government has full powers with respect to treaty making and responsibility for international trade. Despite this situation, the provinces are increasingly important players on trade issues. This situation is explained by the fact that trade negotiations are increasingly affecting provincial jurisdictions and the federal government can not impose its treaties on the provinces.

According to several experts, provinces (and even Canadian territories) are increasingly important players in Canada's trade negotiations (Kukucha, 2016; Ouellet \& Beaumier, 2016; VanDuzer, 2013). Although the federal government has full constitutional authority over treaty-making and sole responsibility for international trade, Grace Skogstad has gone so far as to call the trade negotiation process "of facto shared jurisdiction "(Skogstad, 2012).

After the Second World War, Canada's trade policy was essentially structured by its participation in the GATT negotiations. Prior to the 1970s, negotiations were fundamentally about matters that were exclusively federal, 
including the reduction of tariffs (Kukucha, 2016). With the Kennedy Round (1964-1967), but even more clearly with the Tokyo Round (1973-1979), multilateral trade negotiations are beginning to have more and more effect in the provinces' areas of jurisdiction, particularly on non-tariff barriers. It is in this context that the Canadian government introduces advisory mechanisms on federal initiatives that affect international trade. Since subsequent cycles also involve provincial jurisdiction, consultation mechanisms are maintained (Whinham, 1978-1979). With the Uruguay Round negotiations, for example, GATT discussions address issues such as subsidies, dumping, phytosanitary measures, but also agriculture, intellectual property and services.

Initially, federal-provincial consultations on Canada's trade negotiations in the GATT took place in the Canadian Committee on Tariffs and Trade. A few years later, this institution is replaced by the Canadian Trade Negotiations Coordinator (Kukucha, 2016). In this phase of the negotiations, Ottawa's focus is on the implementation of GATT in the areas of provincial jurisdiction. In the 1980s, the European Community and the United States opposed the practice of selling and distributing alcohol, including beer from the Government of Ontario.

These consultations are gaining importance as international negotiations increasingly focus on internal policies, including business subsidies or provincial or local regulations, which distort or obstruct international trade. Policies on the price of natural resources and support for agriculture are just two examples of provincial constitutional issues that are beginning to be addressed at international economic conferences. Beginning in 1980, this approach was institutionalized with the establishment of periodic federal-provincial trade policy consultations (Whinham, 1978-1979).

\subsection{Global Economic and Trade Agreement}

In May 2009, the European Union and the Canadian government announced the launch of trade negotiations for a new generation free trade agreement, and for the first time in Canadian history that the provinces would be represented on the bargaining team (Kukucha, 2013; VanDuzer, 2013).

In the particular case of CETA, provincial participation in trade negotiations stems from a requirement of the European Union that made it a condition for launching negotiations. Based on the failures of past negotiations, the European Union has ruled that representatives of the provinces must be present in order for the negotiations to be successful. One of the reasons for this is the European Union's interest in Canadian public procurement, which is an area of provincial jurisdiction.

Compared with previous trade liberalization negotiations, including those with the United States, the provinces have seen their role grow at virtually every stage of the bargain. Although they were not consulted during the chief negotiator's selection process, Steve Verheul, they were consulted at the crucial stages of writing the joint report and in formulating the negotiating mandate. During the parameterization exercise, the provinces were also consulted on issues related to their areas of jurisdiction. In addition, during the entire negotiation, they had access to the negotiating documents and were very widely consulted. Quebec, for example, presented more than 150 strategic positioning notes8. In addition, "over 275 meetings involving federal negotiators and their provincial-territorial counterparts, numerous meetings of provinces and territories with common interests and closed-door bilateral meetings between a province or territory and federal negotiators" took place (Johnson, Muzzi, \& Bastien, 2015).

Provinces, however, did not have access to all bargaining topics. They have thus actively participated in discussions on technical barriers to trade, regulatory cooperation, investment, including the State-investor dispute settlement mechanism, cross-border trade in services, mutual recognition of professional qualifications, public procurement, public monopolies and Crown corporations, sustainable development (labor and environment), wine and spirits and co-operation (raw material and innovation and research in science and technology). However, they have been largely excluded from discussions related to agriculture, customs procedures and trade facilitation (origin rule and origin procedure), phytosanitary measures, trade remedies, subsidies, transport and temporary entry, financial services, telecommunications, e-commerce, intellectual property (geographical designations and patents), competition policies and institutional issues, and bilateral cooperation on biotechnology (Paquin, 2013).

\subsection{Core Principles and Obligations}

The main principles of Canada's trade agreements are direct reflecting on how to do business. The main principles include non-discrimination and justice. The principle of non-discrimination is the duty of the Most Favored Nations (MFN) and is part of the national treatment involved in most of the agreements.

According to this principle, Canada should be equated with all its trading partners and can not differentiate 
against its partners. Canada must treat businesses similaly from different countries. Canada has been forced to be transparent with domestic laws, regulations, programs and administrative procedures for foreign businesses.

\section{Canada's Sanctions}

The issue of international sanctions compliance has recently become one of the most important challenges for large corporations, operating worldwide. It is obvious that in the epoch of globalization modern business environment is to a large extent dependent on economic and political processes that can be observed all over the world, therefore, creating additional risks for companies, managing units in various jurisdictions. From the historical perspective, economic sanctions, asset-freezing measures and product embargoes are not a new instrument, applied by regulators. However, today's main concern, associated with them, is a fast increase in the scope and area of their application, and, therefore, a requirement for businesses to take additional control measures to ensure the corresponding compliance.

There are five legal instruments that Canada can use to apply sanctions. The instrument depends not on the measures or targets, but rather on who or what is the initiating authority calling for sanctions, i.e. which organization/states or coalitions have decided to apply sanctions measures. Via these standing Acts, Canada creates ad hoc regulations for each sanctions regime. In all cases, a number of federal departments are involved in the drafting of Canada's legislation, most notably Justice and Canadian Customs and Border Services Agency (CBSA). However, the "pen" for all of Canada's sanctions regulations is the DFATD Minister on behalf of the Governor in Council. The Minister of Foreign Affairs, therefore, is ultimately responsible for the administration and enforcement of the Acts listed below. In practice, this power is devolved to the Royal Canadian Mounted Police (RCMP) and the Canada Border Services Agency (CBSA) to enforce the statutes and their regulations.

- United Nations Act;

- $\quad$ Special Economics Measures Act;

- $\quad$ Area Control Lists;

- $\quad$ Freezing Assets of Corrupt Foreign Affairs Act (FACOFA);

- Diplomatic Sanctions.

Canada's sanctions against certain countries, organizations or individuals vary and may include many measures, including the restriction or prohibition of trade, financial transactions or other economic activity between Canada and the United States. State concerned, or the seizure or freezing of property in Canada.

Embargo on arms and related materiel - An arms embargo is aimed at preventing the entry or exit of weapons or military equipment in the case of a targeted country. It prohibits the export and import of arms and related materiel in the case of a targeted country, and may also prohibit the disclosure of technical data or financial transactions relating to military activities.

Freeze of assets - An asset freeze is designed to prevent a person or entity from accessing property or other assets that it may hold in Canada. It prohibits any person in Canada and Canadians outside Canada from carrying out any transaction in respect of property held by or on behalf of a person named in the applicable penalty regulations. It also prohibits supporting or providing financial services related to such transactions.

Export and import restrictions - Export and import restrictions are intended to restrain the economy, or specific sectors of the economy, of the target country. They generally prohibit the purchase, sale or shipment of designated goods to or from the targeted country, such as petroleum products or certain telecommunications products.

Financial prohibitions - Financial prohibitions prevent people in Canada and Canadians abroad from engaging in financial transactions with registrants on their behalf or on their instructions. In addition, they may target certain types of financial transactions with listed individuals or entities.

Prohibitions on technical assistance - Prohibitions on technical assistance are intended to prevent a country subject to an arms embargo or export ban from obtaining services and information relating to prohibited products. They generally defend the provision of technical data, training or other forms of technical assistance. Prohibitions on technical assistance will generally affect transactions with anyone in the country.

\section{Conclusion}

It is up to the Canadian government to take some measures in the framework of improving its relationship with important international organizations, which would also affect the improvement of its image.

Initially, the government should try to lower the "tensions" with the political organizations we can say as the UN 
Security Council and General Assembly. The Government of Canada must accept the fact that from time to time decisions can go beyond its will, but being cautious can help the Canadian government to have an impact on decision making.

The government of Canada must make a review of all international organizations where it is part by checking their objectives and mandates and the way they perform their duties. The government should take action to ensure that Canada takes part in institutions related to important global issues of our time.

Canada has a role to play in all international debates on the world's future. A government such as Canada is more likely to offer a positive attitude than a bias against what Arthur Stein calls "the existential reality of multilateralism" (Stein, 2008). Sometimes, international organizations are a good opportunity to change many things in the world and it would be a disaster for the Canadian government not to use it.

\section{References}

Alexander, T., \& Duncan, S. (1999). International Organization (p. 706). University of Chicago.

Arthur, S. (2008). Incentive compatibility and global governance. In A. Alexandroff (Ed.), Can the World be Governed. WLU Press.

Charls, K. (n. d.). World Politics (p. 157).

Ferry, de K. (2008). Multilateralism on Trial. In A. Alexandroff (Ed.), Can the World be Governed. WLU Press.

Johnson, P. M., Patrick, M., \& Véronique, B. (2015). Le Québec et l'AECG. Dans C. Deblock, J. Lebulanger, \& S,Paquin (dirs.), Un nouveau pont sur l'Atlantique: l'Accord économique et commercial global entre l'Union européenne et le Canada Québec (p. 351). Presses de l'Université du Québec.

Karen, M. (2008). Fundamentals of International Relations (p. 210). AIIS, Tirana.

Kukucha, C. (2016). Provincial/Territorial Governments and the Negotiations of International Trade Agreements. IRPP Insight, (10), 1-16.

Miles, K. (1992). Multilateralism with Small and Large Numbers. International Organization, 46(3).

Orinda, M. (2009). Role and Function of International Organizations.

Orinda, M. (n. d.). Classification of International Organizations.

Ouellet, R., \& Guillaume, B. (2016). l'activité du québec en matière de commerce international: de l'énonciation de la doctrine Gérin-Lajoie à la négociation de l'AECG. Revue QuÉBÉCoise de Droit International, Horssérie, juin, 67-79.

Skogstad, G. (2012). International Trade Policy and the Evolution of Canadian Federalism. In H. Bakvis, \& G. Skogstad (Eds.), Canadian Federalism (3rd ed.). Don Mills, Oxford University Press.

Tony, B. (2007). Speech at Davos, January 27, 2007.

Vanduzer, A. (2013). Could an Intergovernmental Agreement Make Canadian Treaty Commitments in Areas within Provincial Jurisdiction More Credible? International Journal, 68(4), 536-544. https://doi.org/10.1177/0020702013509315

Whinham, G. R. (1978-1979). Bureaucratic Politics and Canadian Trade Negotiation. International Journal,. 34(1), 64-89. https://doi.org/10.2307/40201720

\section{Note}

Note 1. http://www.intergovernmentalorganizations.org/

\section{Copyrights}

Copyright for this article is retained by the author(s), with first publication rights granted to the journal.

This is an open-access article distributed under the terms and conditions of the Creative Commons Attribution license (http://creativecommons.org/licenses/by/4.0/). 